\title{
Peran Budaya Organisasi dan Komitmen Organisasi untuk Meningkatkan Kinerja Karyawan di RSU Muhammadiyah Ponorogo
}

\author{
Umi Farida' ${ }^{1}$, Widya Belle Pransiska ${ }^{2}$ \\ Universitas Muhammadiyah Ponorogo ${ }^{1}$, \\ Universitas Muhammadiyah Ponorogo ${ }^{2}$ \\ umifarida899@gmail.com ${ }^{1}$, widyabelle@gmail.com ${ }^{2}$
}

\begin{abstract}
This research aims to determine the role of organizational culture and organizational commitment to improve employee performance at Muhamadiyah Ponorogo Hospital. There are several factors to improve employee performance, one of them is the organizational culture and organizational commitment which is well implemented according to hospital policy. Muhammadiyah general hospital as a research location with a number of respondents 105 employees with the technique used namely purposive sampling. Multiple regression analysis as a data analysis technique used to determine the role of organizational culture and organizational commitment to improve employee performance both partially and simultaneously. The results of the study show that organizational culture has a role in improving employee performance and organizational commitment also has a role on employee performance individually, while together organizational culture and organizational commitment have a role on employee performance, while the two variables are the most dominant its role is organizational commitment.
\end{abstract}

Keywords: organizational culture, organizational commitment and employee performance

\begin{abstract}
Abstrak
Penelitian ini bertujuan untuk mengetahui peran Budaya Organisasi dan Komitmen Organisasi untuk meningkatkan kinerja karyawan di Rumah Sakit Umum Muhammadiyah Ponorogo. Ada beberapa faktor untuk meningkatkan kinerja karyawan, salah satu yang dapat meningkatkan kinerja karyawan adalah Budaya Organisasi dan Komitmen organisasi yang dilaksanakan dengan baik sesuai kebijakan rumah sakit. Rumah Sakit Umum Muhammadiyah sebagai lokasi penelitian dengan jumlah responden 105 karyawan dengan teknik yang digunakan yaitu Purposive smpling. Analisis Regresi Berganda sebagai teknik analisis data yang digunakan untuk mengetahui peran budaya organisasi dan komitmen organisasi terhadap peningkatan kinerja karyawan baik secara parsial maupun secara simultan. Hasil penelitian diketahui bahwa budaya organisasi mempunyai peran terhadap peningkatan kinerja karyawan dan komitmen organisasi juga mempunyai peran terhadap kinerja karyawan secara sendiri-sendiri, sedangkan secara bersama-sama budaya organisasi dan komitmen oganisasi mempunyai peran terhadap kinerja karyawan, sedangkan dari kedua variabel tersebut yang paling dominan perannya adalah komitmen organisasi.
\end{abstract}

Kata kunci: Budaya Organisasi, Komitmen Organisasi dan Kinerja Karyawan. 


\section{PENDAHULUAN}

Karyawan merupakan faktor yang penting dalam melaksanakan tugas, karena karyawan karyawan berpera dalam hal perencanaan, pelaku dan penentu terwujudnya tujuan organisasi. Salah satu keberhasilan Organisasi ditentukan dari keberhasilan mengelola karyawan. Pengelolaan karyawan dimaksud untuk organisasi harus mampu menyatukan cara pikir karyawan dan pimpinan organisasi agar tujuan organisasi dapat tercapai.

Sebagai salah satu lembaga kesehatan, Rumah Sakit Umum Muhammadiyah berusaha meningkatkan kualitas pelayanan kesehatan untuk masyarakat sekitarnya. Peningkatan Kualitas pelayanan yang dilakukan dengan meningkatan kinerja karyawannya dalam melakukan tugas dan kewajibannya. Tingkat kompetensi dari karyawan itu sendiri dapat ditunjukkan dari kinerja karyawan. Kinerja karyawan dapat dijadikan tolak ukur berhasilnya suatu organisasi. Salah satu kesuksesan organisasi akan dipengaruhi oleh kinerja karyawan karena karyawan yang mempunyai kinerja baik dan mereka akan merancang dan mengaplikasikan semua rancangannya serta dijadikan suatu target organisasi. Karyawan dikatakan berprestasi apabila mempunyai kinerja yang tinggi serta dapat menyelesaikan tugas secara efisien dan efektif. Oleh karena itu penelitian tentang peran Budaya Organisasi dan Komitmen Organisasi dalam rangka penigkatan kinerja karyawan penting dilakukan karena dengan mengetahui hal tersebut akan mempermudah organisasi untuk mencapai tujuan.

Berdasarkan wawaancara dengan Manajer Rumah Sakit, menyatakan bahwa secara prosentasi ada penurunan kinerja pegawai sekitar 22\%, dengan penurunan kinerja tersebut dikhawatirkan akan berdampak pada kurangnya kepercayaan pasien untuk berkunjung ke rumah sakit. Oleh karena itu peningkatan kinerja karyawan menjadi sangat penting diperhatiakan. Penyebab kinerja penurun karena budaya organisasi yang kurang diperhatikan dan Komitmen karyawan terhadap organisasi yang kurang. Definisi budaya organisasi menurut Edy Sutrisno (2010:2) adalah sebagai perangkat system nilai-nilai, keyakinan-keyakinan, asumsi-asumsi, atau norma-norma yang telah diberlakukan, disepakati dan diikuti oleh para anggota suatu organisasi sebagai dasar perilaku dan pemecahan masalahmasalah organisasinya. Oleh karena itu budaya organisasi perlu diperhatikan dengan seksama agar tujuan perusahaan dapat tercapai.

Definisi komitmen organisasi menurut Luthas dalam Sutrisno (2010:292) merupakan: 1. Keinginan yang kuat untuk menjadi anggota organisasi. 2. Kemauan usaha yang tinggi untuk organisasi. 3. Suatu keinginan tertentu dan penerimaan terhadap nilai-nilai dan tujuan organisasi.

Menurut penelitian-penelitian terdahulu yang ditulis oleh Yunita Sari Mustakiningsih dan rini Handayani dengan judul "Pengaruh Gaya Kepemimpinan, Budaya Organisasi, Komitmen Organisasi dan Remunerasi terhadap kinerja karyawan" di Optic Pranoto Surakarta, yang hasil uji Hipotesis menyatakan gaya kepemimpinan, komitmen organisasi dan remunerasi berpengaruh terhadap kinerja namun budaya organisasi tidak 
Peran Budaya Organisasi dan Komitmen Organisasi untuk Meningkatkan Kinerja Karyawan di RSU Muhammadiyah Ponorogo

berpengaruh, sedangkan remunerasi merupakan faktor yang paling mempengaruhi kinerja karyawan, dari perbedaan hasil penelitian ini maka perlu adanya penelitian lebih lanjut terkait dengan budaya organisasi dan komitmen organisasi, sehingga berdasarkan permasalahan diatas penulis ingin meneliti lebih dalam mengenahi "Peran Budaya Organisasi, dan Komitmen Organisasi terhadap kinerja karyawan RSU. Muhammadiyah Ponorogo.

Budaya organisasi yang sesuai dengan harapan dan karyawan yang berkomitmen organisasi dengan serasi merupakan hal yang dapat meningkatkan kinerja karyawan. Dengan demikian hal-hal yang menjadi sentral permasalahan dalam kajian ini adalah: 1). Apakah budaya organisasi dan komitmen organisasi mempunyai peran terhadap peningkatan kinerja karyawan di RSU. Muhammadiyah Ponorogo, baik secara parsial maupun secara simultan. 2). Untuk mengetahui diantara dua variabel tersebut mana yang paling utama perannya terhadap peningkatan kinerja karyawan di Rumah Sakit Umum. Muhammadiyah Ponorogo.

Penelitian ini bertujuan: 1. Untuk mengetahui budaya organisasi dan komitmen organisasi mempunyai peran terhadap peningkatan kinerja karyawan di Rumah Sakit Umum. Muhammadiyah Ponorogo, baik secara sendiri-sendiri maupun secara bersama-sama. 2. Untuk mengetahui diantara dua variabel, mana yang paling utama perannya terhadap peningkatan kinerja karyawan di Rumah Sakit Umum. Muhammadiyah Ponorogo.

\section{KAJIAN LITERATUR}

\section{Kinerja Pegawai}

Berdasarkan buku manajemen Mutu Sumber Daya Manusia yang dikarang oleh Mangkuprawira dan Hubeis (2007: 153) Mendefinisikan kinerja adalah hasil pekerjaan yang terencana baik pada waktu dan tempat dari pegawai dalam organisasi tersebut. Murpy dan Cleveland dalam Pasalog (2007: 175) mengatakan bahwa, kinerja adalah kualitas perilaku yang berorientasi pada tugas dan pekerjaan.

\section{Budaya organisasi}

Berdasarkan buku perilaku organisasi yang dikarang oleh Stephen P. Robbins (2003: 721) mengatakan budaya organisasi adalah sistem makna secara seksama yang diselenggarakan oleh anggota sehingga membedakan dalam organisasi.

Defenisi budaya organisasi menurut Edy Sutrisno (2010: 2) sebagai perangkat Values, keyakinan-keyakinan, assumptions, atau norma-norma yang telah lama berlaku, dan pemecahan masalah-masalah organisasinya.

\section{Komitmen Organisasi}

Definisi komitmen oranisasi menurut Luthas dalam sutrisno (2010: 292) menjelaskan: 1) kemauan yang kuat untuk menjadi anggota organisasi. 2) kemauan bekerja yang tinggi untuk organisasi. 3) suatu kepercayaan tertentu dan diterimanya nilai-nilai dan tujuan organisasi, sedangkan pendapat Sutrisno (2010: 296) definisi komitmen karyawan itu merupakan hal yang 
perlu diperhatikan bagi organisasi, utamanya untuk menjalin kelangsungan hidup organisasi dan untuk pencapaian tujuan.

\section{Kerangka pemikiran}

Berdasarkan pendapat diatas maka bisa dibuat kerangka pikir penelitian ini, sedangkan kerangka pikirnya adalah:

\section{Gambar 1.1 Kerangka Pikir}

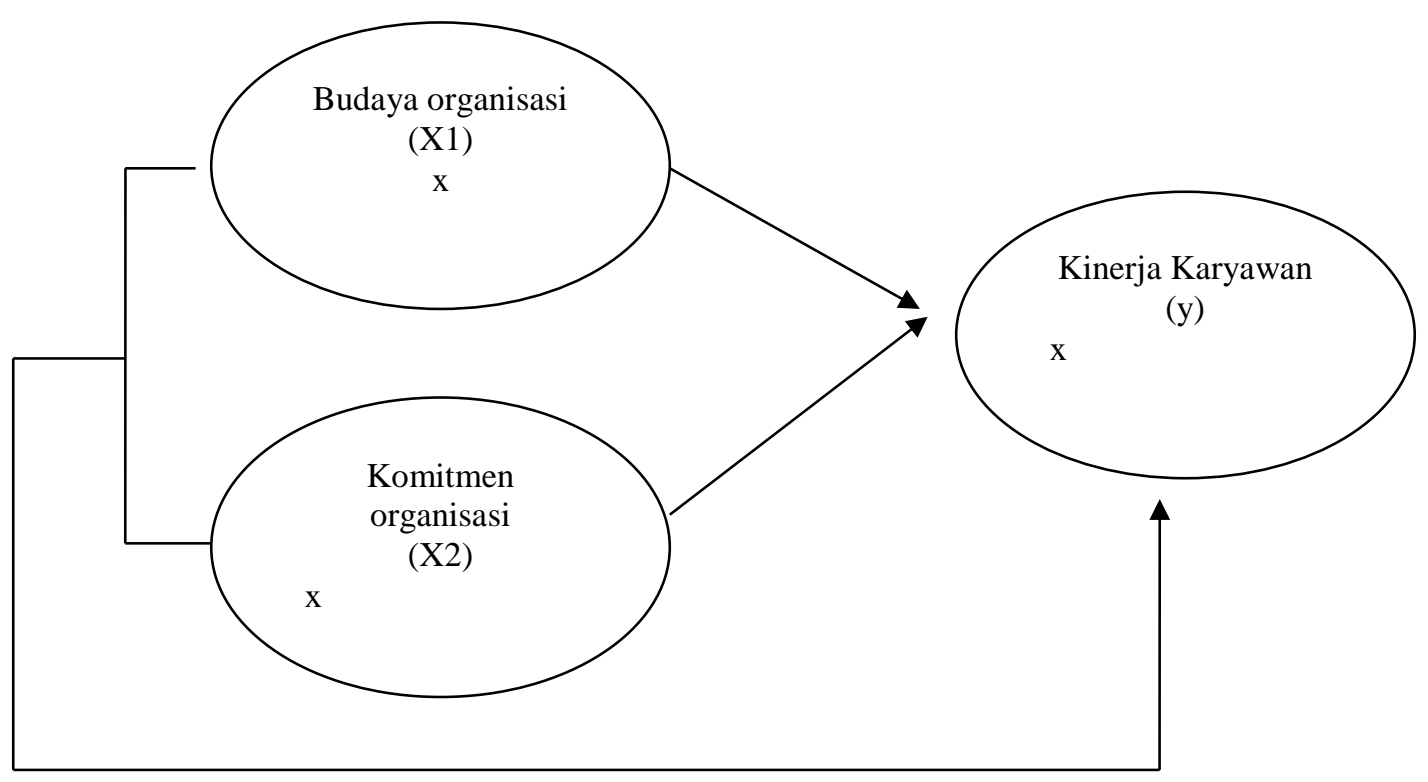

\section{Hipotesis}

Berdasarkan kerangka pemikiran diatas, maka dapat dirumuskan hipotesisnya antara lain:

Ha1: Bahwa Budaya Organisasi mempunyai peran terhadap peningkatan kinerja karyawan di Rumah Sakit Umum Muhammadiyah Ponorogo, baik secara sendiri-sendiri maupun bersama-sama.

Ha2: Komitmen Organisasi paling dominan perannya terhadap peningkatan kinerja karyawan di RSU Muhammadiya Ponorogo.

\section{METODE PENELITIAN}

Penelitian ini disebut penelitian kuantitatif yang berkaitan dengan kinerja karyawan di RSU Muhammadiyah Ponorogo. Variabel yang diteliti antara lain: budaya organisasi, komitmen organisasi dan kinerja karyawan. Ruang lingkup penelitian ini adalah karyawan di RSU Muhammadiyah Ponorogo. Populasi dalam penelitia ini yaitu seluruh karyawan RSU Muhammadiyah Ponorogo, kecuali dokter yang masa kerjanya lebih dari satu tahun yang berjumlah 210 orang. Menurut Suharsimi Arikunto (2008) penetuan pengambilan sampel adalah apabila subyek kurang dari 100 maka lebih baik diambil semua populasi, sehingga penelitian ini merupakan penelitian populasi. Jika jumlah subyeknya besar maka dapat diambil antara $10-15 \%$ atau $20-55 \%$ dari jumlah populasi atau lebih. 
Berdasakan pendapat tersebut diatas dikarenakan jumlah populasi lebih dari 100, peneliti mengambil sampel 50\% dari populasi yaitu 50\% x $210=105$ karyawan.

Peneliti ini berusaha menggali data mengenai budaya organisai, komitmen organisasi dan kinerja karyawan melalui wawancara dan kuisioner. Data yang digunakan dalam penelitian ini adalah data primer dan data sekunder. Data priner diperoleh dari penyebaran kuisioner, sedangkan data sekender didapat dari wawancara.

\section{Definisi operasional variabel}

Ada dua variabel dalam penelitian ini yaitu variabel independen (X) dan variabel dependen (Y), sedangkan untuk memperjelas dari pengertian variabel dalam penelitian ini, maka definisei opersaionalnya sebagai berikut :

Variabel Budaya Organisasi (X1)

Indikator budaya organisasi menurut Robbins dalam Buku Pabundu Tika (2006: 10) meliputi:

1. Inisiatif Individu

2. Toleransi terhadap tindakan yang beresiko

3. Pengarahan

4. Integrasi

5. Dukungan dari manajemen

6. Kontrol

7. Identitas

8. Sitem imbalan

9. Toleransi terhadap konflik

10. Pola-pola komunukasi.

\section{Komitmen organisasi (X2)}

Indikator komitmen organisasi menurut Robbins judge (2009:101) meliputi:

1. Komitmen afektif yaitu perasaan emosional untuk organisasi dan keyakinan dalam nilai-nilainya.

2. Komitmen berkelanjutan yaitu nilai ekonomi yang dirasa dari bertahan dalam suatu organisasi bila dibandingkan dengan meninggalkan organisasi tersebut.

3. Komitmen normative yaitu kewajiban untuk bertahan dalam organisasi untuk alasan-alasan moral atau etis

\section{Variabel kinerja Karyawan (Y)}

Menurut Berdandin dan Russel dalam Gomes (2003) indikator kinerja Karyawan meliputi:

1. Kualitas kerja

2. Kuantitas kerja

3. Pemahaman pekerjaan

4. Kretifitas

5. Kerjasama

6. Kesadaran dan kepercayaan diri

7. Inisiatif 
8. Kualitas diri

\section{Metode Analisis}

Uji Instrumen yang terdiri dari Uji validitas dan Reliabilitas

\section{Uji validitas}

Kegunaan uj validitas untuk mengetahui valid atau tidaknya item kuisioner. Berdasarkan pengujian validitas dari semua indikator pertanyaan dalam penelitian ini dinyatakan valid dengan taraf signifikansi 0,05 dan derajat kebebasan $d k=n-1$ atau $d k=105-1$ adalah 104, sehingga $r$ table sebesar 0,191. Uji validitas semua item kuisioner di dapat $r$ hitung $>r$ table dan bernilai positif, maka data penelitian ini bersifat valid.

\section{Uji Reliabilitas}

Uji reliabilitas menurut Sugiyono (2010: 354) digunakan untuk mengetahui seberapa besar hasil pengukuran tetap sama apabila dilakukan pengukuran dua kali atau lebih terhadap gejala yang sama dengan alat pengukur yang sama.

Alat analisis yang digunakan adalah:

1. Regresi linier berganda, rumus yang digunakan dari pendapat sugiyono(2003)

$\mathrm{Y}=\mathrm{a}+\mathrm{b}_{1} \mathrm{X}_{1}+\mathrm{b}_{2} \mathrm{X}_{2}+\ldots . . \mathrm{b}_{\mathrm{n}} \mathrm{X}_{\mathrm{n}}+\mathrm{e}$

Keterangan:

$\mathrm{X}_{1}$ : Budaya Organisasi

$\mathrm{X}_{2}$ : Komitmen Organisasi

Y : Kinerja Karyawan

E : Standart Eror

2. Analisis koefisien Determinasi

Menurut Slamet Santoso (2013) koefisien determinasi berfungsi untuk menentukan besarnya variasi variabel dependen yang dapat dijelaskan oleh variabel independen.

Nilai $\mathrm{R}^{2}$ digunakan rumus sebagai berikut:

$$
\mathrm{R}^{2}=\frac{\left(\mathrm{b}_{1} \sum \mathrm{x}_{1} \mathrm{y}+\mathrm{b}_{2} \sum \mathrm{x}_{2} \mathrm{y}\right)}{\sum \mathrm{y}^{2}} \quad \text { dimana } 0 \leq \mathrm{R}^{2} \leq 1
$$

Diketahui:

$\mathrm{R}^{2}=$ Koefisien determinasi

Koefisien determinasi yang mendekati 1 maka variabel dependen dapat diprediksikan dengan menggunakan hampir semua informasi yang diberikan oleh variabel Independen.

\section{Uji Hipotesis}

Uji hipotesis yang digunakan dalam penelitian ini yaitu uji f dan uji $t$

\section{Hasil uji t}

Uji t berfungsi untuk mengetahui apakah ada pengaruh secara sendiri-sendiri (parsial) antara variabel independen dan variabel dependen secara signifikan atau tidak. 
Tingkat signifikan terhadap pengujian ini 0,05 dimana, jika anggota probabilitas signifikan $<0,05$ maka Ho di tolak dan Ha diterima, dan sebaliknya jika angka probabilitas $>0,05$ maka Ho diterima dan Ha ditolak.

\section{Hasil Uji F}

Menurut Slamet Santoso (2013:134), mengatakan yang dimaksud uji F adalah untuk menguji tingkat signifikan dari pengaruh variabel independen secra bersama-sama dengan variabel dependen. Apabila nilai hasil uji f hitung $<0,05$ $(\grave{\alpha}=5 \%)$, dan atau jika $\mathrm{f}$ hitung $>\mathrm{f}$ table maka variabel independen secara bersama-sama berpengaruh signifikan terhadap variabel dependen.

\section{PEMBAHASAN}

\section{Uji Instrumen}

Dalam penelitian ini berdasarkan pengujian validitas dari seluruh indikator pertanyaan dinyatakan valid dengan derajat kebebasan $\mathrm{dk}=\mathrm{n}-1$ atau $\mathrm{dk}=105$ 1 adalah 104, dengan taraf signifikansi 0,05 sehingga hasilnya $r$ table 0,191. Uji validitas semua item kuisioner atau pertanyaan memiliki $r$ hitung $>$ r table dan bernilai positif, maka item pertanyaan dalam penelitian ini bersifat valid dan layak. Berdasarkan uji Reliabilitas dari semua indikator pertanyaan dalam penelitian ini dinyatakan reliable karena hasilnya melebihi nilai kritis 0,6 sehingga bisa dikatakan hasil pengukuran tetap konsisten.

\section{Analisis Regresi Berganda}

Model analisis regresi berganda ini dipakai untuk mengetahui peran variabel independen (Budaya organisasi dan komitmen organisasi) terhadap variabel dependen (kinerja karyawan). Hasil pengolahan data menggunakan program SPSS 16 adalah

Tabel 1

Analisis Regresi Linier Berganda

Coefficients $^{\mathrm{a}}$

\begin{tabular}{|c|c|c|c|c|c|c|}
\hline \multirow{2}{*}{\multicolumn{2}{|c|}{ Model }} & \multicolumn{2}{|c|}{$\begin{array}{l}\text { Unstandardized } \\
\text { Coefficients }\end{array}$} & \multirow{2}{*}{$\begin{array}{c}\text { Standardized } \\
\text { Coefficients } \\
\text { Beta }\end{array}$} & \multirow[b]{2}{*}{$\mathrm{t}$} & \multirow[b]{2}{*}{ Sig. } \\
\hline & & B & Std. Error & & & \\
\hline \multirow[t]{3}{*}{1} & (Constant) & 9.073 & 5.888 & & 1.541 & .127 \\
\hline & $\begin{array}{l}\text { Budaya } \\
\text { Organisasi }\end{array}$ & .169 & .068 & .181 & 2.489 & .014 \\
\hline & $\begin{array}{l}\text { Komitmen } \\
\text { Organisasi }\end{array}$ & .296 & .055 & .426 & 5.410 & .000 \\
\hline
\end{tabular}

a. Dependent Variable:

Kinerja Karyawan

Sumber: Data yang diolah melalui SPSS 16

1. Variabel budaya organisasi $\left(\mathrm{X}_{1}\right)$ terhadap kinerja karyawan. 
Nilai koefisien budaya organisasi $\left(\mathrm{X}_{1}\right)$ senilai 0,169 , menggambarkan bahwa budaya organisiasi mempunyai nilai positif yang berarti Budaya Oranisasi mempunyai peran positif terhadap kinerja karyawan dan apabila Budaya Organisasi ditingkatkan satu satuan sehingga akan berperan penigkatan kinerja karywan 0,169.

2. Variabel Komitmen organisasi $\left(\mathrm{X}_{2}\right)$ terhadap kinerja karyawan yang hasil koefisien sebesar 0,296, menggambarkan bahwa komitmen organisasi mempunyai nilai positif artinya komitmen organisasi mempunyai peran terhadap kinerja karyawan dan apabila komitmen organisasi ditingkatkan satu satuan sehingga akan berperan juga peningkatan kinerja karyawan senilai 0,296 .

\section{Koefisien determinasi}

Kegunaan koefisien determinasi untuk mengetahui seberapa besar variasi variabel dependen (Y) yang dapat di prediksikan oleh variabel independen yaitu Budaya organisasi $\left(\mathrm{X}_{2}\right)$, dan Komitmen Organisasi $\left(\mathrm{X}_{2}\right)$, secara simultan.

Tabel 2

Analisis Koefisien Determinasi

Model Summary

\begin{tabular}{|l|r|r|r|r|}
\hline Model & $\mathrm{R}$ & \multicolumn{1}{|c|}{ R Square } & \multicolumn{1}{c|}{$\begin{array}{c}\text { Adjusted R } \\
\text { Square }\end{array}$} & \multicolumn{1}{c|}{$\begin{array}{c}\text { Std. Error of the } \\
\text { Estimate }\end{array}$} \\
\hline 1 & $.765^{\mathrm{a}}$ & .585 & .573 & 1.81324 \\
\hline
\end{tabular}

a. Predictors: (Constant), Komitmen Organisasi, Remunerasi, Budaya Organisasi

Berdasarkan table 2 dijelaskan bahwa koefisiesn determinasi atau $\mathrm{R}$ Square senilai 0,585 yang berarti bahwa kinerja karyawan (variabel dependen) dapat dijelaskan oleh budaya organisasi dan komitmen organisasi (variabel Independen) senilai 58,5\% dan sisanya 41,5\% diperankan oleh faktor-faktor lain yang tidak diamati oleh peneliti, berarti korelasi memiliki keeratan sedang.

\section{Pengajuan Hipotesis}

Menurut Ghozali (2011:143) hipotesisnya adalah berkaitan dengan ada tidaknya peran yang signifikan dari Budaya Organisasi dan Komitmen Organisasi terhadap kinerja karyawan baik secara sendiri-sendiri maupun secara bersama-sama.

Uji t

Pengujian ini dijalankan dengan membandingkan t hitung dengan $t$ table menggunakan taraf keyakinan 5\% atau 0,05.

Kriterianya adalah sebagai berikut: 
Peran Budaya Organisasi dan Komitmen Organisasi untuk Meningkatkan Kinerja Karyawan di RSU Muhammadiyah Ponorogo

Jika t hitung > t table maka Ho ditolak dan Ha diterima yang artinya: ada peran antara budaya organisasi dan komitmen organisasi terhadap kinerja karyawan.

Jika t hitung < t table maka Ho diterima Dan Ha ditolak yang berarti tidak ada peran antara budaya organisasi dan komitmen organisasi terhadap kinerja karyawan.

Penjelasan penghitungan dari masing-masing variabel secara sendiri-sendiri sebagai berikut:

Berdasarkan hasil penghitunagn table 1 di atas dapat diterangkan bahwa analisis uji t untuk budaya organisasi atau variabel $\mathrm{X}_{1}$ didapatkan hasil senilai 2,489 dan terbukti nilai t table 1,983, sehingga t hitung 2,489 > t table 1,983 dan atau 0,014<0,05 maka Ho ditolak dan Ha diterima, yang berarti artinya ada peran positif dan signifikan antara budaya organisasi dengan kinerja karyawan RSU Muhammadiya Ponorogo, sedangkan untuk komitmen organisasi atau variabel $\mathrm{X}_{2}$ didapat hasil t hitung senilai 5,410 dan hasil t tabel dengan taraf signifikan $5 \%$ senilai 1,983 , sehingga t hitung $(5,410)>$ table $(1,983)$ dan atau $0,000<0,05$, maka Ho ditolak dan Ha diterima, yang berarti ada peran positif dan signfikan antara komitmen organisasi dengan kinerja karyawan RSU Muhammadiyah Ponorogo.

\section{Uji F}

Pengujian tingkat signifikan dari peran variable independen secara bersama sama terhadap variabel dependen atau uji f menurut Santoso Slamet (2013:134).

Jika f hitung $>$ f table nilai $<0,05(\grave{\alpha}=5 \%)$, maka variabel organisasi dan komitmen organisasi (variabel Independen) secara bersama-sama berperan signifikan terhadap kinerja karyawan (variabel dependen).

Table 3

Hasil Uji $\mathrm{f}$

ANOVAb $^{b}$

\begin{tabular}{|l|r|r|r|r|r|}
\hline \multicolumn{1}{|l|}{ Model } & Sum of Squares & Df & Mean Square & F & Sig. \\
\hline $1 \quad$ Regression & 468.919 & 3 & 156.306 & 47.541 & $.000^{\mathrm{a}}$ \\
\multicolumn{1}{|l|}{ Residual } & 332.072 & 101 & 3.288 & & \\
\multicolumn{1}{|l|}{ Total } & 800.990 & 104 & & & \\
\hline
\end{tabular}

a. Predictors: (Constant), Komitmen Organisasi, Remunerasi, Budaya Organisasi

b. Dependent Variable: Kinerja Karyawan

Sumber: Data yang diolah melalui SPSS 16. 
Berdasarkan hitungan secara bersama-sama didapatkan hasil uji $\mathrm{f}$ hitung senilai 47,541, dan untuk nilai $\mathrm{f}$ table pada tingkat signifikan 0,05 dengan df 1 (jumlah jumlah variabel -1) =3, dan df 29 (n-k-1) atau 105-3-1= 101, maka diperoleh hasil untuk f table senilai 2,69. Demikian dapat disimpulkan bahwa f hitung $>\mathrm{f}$ table yang berarti bahwa variabel budaya organisasi dan komitmen organisasi secara serempak berperan terhadap variable Kinerja karyawan di RSU Muhammadiyah Ponorogo.

Berdasarkan hasil analisis deskriptif dalam penelitian ini menunjukkan bahwa jawaban responden terhadap kuisioner sudah sangat baik. Hal ini ditunjukkna dengan banyaknya jawaban yang setuju dari masing masing indikator, sedangkan hasilnya sebagai berikut:

\section{Peran Budaya Organisasi terhadap kinerja karyawan di RSU Muhammadiyah Ponorogo}

Berdasarkan hasil penelitian ini membuktikan bahwa budaya organisasi berperan secara positif dan signifikan terhadap kinerja karyawa, karena dilihat dari uji t menunjukkan diketahui nilai t table 1,983, sehingga $t$ hitung 2,489 > t table 1,983 dan atau 0,014<0,05maka Ho ditolak dan Ha diterima. Artinya budaya organisasi memang perlu diperhatikan oleh karyawan untuk mendapatkan kinerja yang baik. Secara umum responden mengatakan dari item pertanyaan tentang budaya orgnanisasi rata-rata dijawab setuju. Budaya organisasi dapat memperani perilaku individu dalam organisasi karena adanya persamaan persepsi adaptasi dan penyesuaian diri individu akan lebih baik bila nilai-nilai dalam organisasi sesuai harapan setiap karyawan.

Penelitian ini mendukung penelitian hasil penelitian yang dilakuka oleh Haryati Utami (2010) dengan judul pengaruh budaya organisasi, gaya kepemimpinan dan komitmen organisasi terhadap kinerja pegawai Badan Narkotika Nasional di Provinsi Bengkulu. Penelitian ini menyimpulkan bahwa budaya organisasi berpengaruh positif dan signifikan terhadap kinerja pegaewai Badan Narkotika Nasional di Provinsi Bengkulu.

\section{Peran komitmen organisasi terhadap kinerja Karyawan}

Peran komitmen organissi terhadap kinerja karyawan. Pengujia hipotiesis 2 menunjukkan komitmen organisasi berperan positif dan signifikan terhadap kinerja karyawan RSU Muhammadiyah Ponorogo. Hasil perhitungan uji t menunjukkna bahwa komitmen organisasi $\left(\mathrm{X}_{2}\right)$ mempunyai t hitung senilai $5,410>t$ table senilai 1,983 dan atau $0,000<0,05$. Hal ini membuktikan komitmen organisasi secara parsial berperan terhadap kinerja karyawan di RSU Muhammadiyah Ponorogo. Hal ini berarti memperjelas kepada karyawan tentang keberlangsungan dan tujuan komitmen organisasi dpat membuat kinerja karyawan semakin baik dan meningkat.

Penelitian ini mendukung hasil penelitian dengan judul pengaruh budaya organisasi, gaya kepemimpinan dan komitmen organisasi terhadap kinerja pegawai Badan Narkotika nasional di provinsi Bengkulu yang dilkukan 
Peran Budaya Organisasi dan Komitmen Organisasi untuk Meningkatkan Kinerja Karyawan di RSU Muhammadiyah Ponorogo

oleh Haryati Utami (2010) dan hasilnya menyimpulkan bahwa budaya organisasi, gaya kepemimpinan dan komitmen organisasi berpengaruh baik secara positif dan signifikan terhadap kinerja pegawau Badan Narkotika Nasional di provinsi Bengkulu.

\section{Variabel yang paling dominan}

Hasil table 1 diatas dapat dilihat bahwa variabel yang sangat berperan dengan kinerja karyawan RSU Muhammadiyah adalah komitmen organisasi, hal ini disebabkan komitmen organisasi di RSU Muhammadiyah Ponorogo memilik $t$ hitung paling besar yaitu 5,410 yang memiliki nilai signifikan si 0,000 sehingga semakin kecil nilai signifikansi maka semakin besar perannya terhadap kinerja karyawan RSU Muhammadiyah Ponorogo.

\section{SIMPULAN}

Hasil pembahasan dari analisis data yang telah diolah pada bab selanjutnya, sehingga dapat ditarik beberapa intisari dari keseluruhan hasil penelitian yaitu:

1. Terhadap peran positif dan signifikan variabel budaya organisasi terhadap peningkatan kinerja karyawan RSU Muhammadiyah Ponorogo. Hal tersebut berdasarkan pengujian hasil uji t dengan nilai thitung 2,489 > t table 1,983, dengan nilai signifikansi sebesar 0,014 .

2. Terdapat peran positif dan signifikan variabel komitmen organisasi terhadap peningkatan kinerja karyawan RSU Muhammadiyah Ponorogo. Hal ini berdasarka hasil uji t dengan nilai t hitung, 5,410 > t table 1,983, denga nilai signifikansi sebesar 0,000.

3. Terdapat peran positif dan signifikan variabel budaya organisasi dan komitmen organisasi secara serempak terhadap kinerja karyawan. Hal ini dibuktikan berlandaskan hasil uji koefisien determinasi yang dilihat dari nilai R Square senilai 0,585 (keeratan sedang). Hal tersebut berarti peran variabel budaya organisasi, dan komitmen organisasi terhadap variabel kinerja karyawan senilai 58,5\% sedangkan selisihnya yaitu 41,5\% dipengaruhi oleh variabel lain yang tidak diteliti.

4. Berdasarkan hasil perhitungan uji t bahwa variabel yang paling berperan dengan kinerja karyawan RSU Muhammadiyah adalah komitmen organisasi, hal ini disebabkan karena komitmen organisasi di RSU Muhammadiyah Ponorogo memiliki thutung paling besar yaitu 5,410, yang memiliki nilai signifikan si 0,000 dimana semakin kecil nilai signifikansi sehingga semakin tinggi penerapannya terhadap kinerja karyawan RSU Muhammadiyah Ponorogo.

\section{DAFTAR PUSTAKA}

Achmad S, Ruky. (2006). Sistem manajemen kinerja. Jakarta: Bumi Aksara.

Aldy Rochmad, Purnomo. (2016). Produser penelitian pendekatan praktik. Jakarta: Rineka Cipta.

Arikunto, Suharsimi. (2008). Penelitian tindakan kelas. Jakarta: Bumi Aksara 
Desseler Gary. (2007). Manajemen sumber daya manusia. Edisi kesepuluh jilid 2. Jakarta: Indeks.

Gomes Faustino Cardoso. (2003). Manajemen sumber daya manusia. Edisi kedua. Yogyakarta: Andi offset.

Gozali Imam. (2011). Aplikasi analisis Multivariate dengan program IBM. SPSS 19 edisi 5. Semarang: Universitas Diponegoro.

Hasibuan Malayu S.P. (2012). Manajemen sumber daya manusia cetakan ke enam belas. Jakarta: Bumi Aksara.

Mahmudi. (2007). Manajemen kinerja publik. Yogyakarta: Unit Penerbit dan Percetakan Sekolah Tinggi Ilmu Manajemen YKPN.

Mangkunegara Anwar Prabu AA. (2005). Perilaku dan budaya organisasi. Bandung: Rafika Aditama.

Mangkunegara Anwar Prabu AA (2010). Manajemen sumber daya manusia edisi kedua. Bandung: Alfabeta

Robbins Stephen dan Coulter, Mary. (2010). Manajemen. Edisi kesepuluh. Jakarta: Erlangga.

Robbins Stephen P judge. (2008). Perilaku organisasi. Edisi ke 12. Jakarta: Salemba Empat.

Santoso Slamet (2013). Statistika ekonomi plus aplikasi SPSS. Ponorogo: Universitas Muhammadiyah Ponorogo.

Sedarmayanti. (2011). Manajemen sumber daya manusia reformasi birokrasi dan manajemen pegawai negeri sipil cetakan kelima. Bandung: Refika Aditama.

Sedarmayanti. (2008). Sumber daya manusia dan produktivitas kerja. TK: Ilham Jaya.

Sugiyono. (2010). Metode penelitian Kuantitatif dan kualitatif dan R \& D. Bandung: Alfabeta.

Tia Pabundu. (2006). Budaya organisasi dan peningkatan kerja perusahaan. Jakarta: Bumi Aksara.

Uma Sekaran. (2006). Metodologi penelitian untuk bisnis buku 1 edisi 4 . Jakarta: Salemba Empat.

Wibowo. (2008). Manajemn Kinerja. Jakarta: Raja Grafindo Persada.

Referensi dari internet:

http://www.landasanteori.com/2015/10/pengertian-penilain-kinerjapegawai.html?m-1

http://dansite.wordpress.com/2009/04/10/pengertian-tujuan-danmanfaat-penilaian-kinerja-karyawan/

http://harisucahyowati.wordpress.com/2009/11/08/komitmenorganisasi/http://070055495.blogspot.co.id/2011/10/bab-iikajian-pustaka--2.html?m=1

http://junaidichaniago.wordpress.com/2010/04/22/download-tabel-flengkap/

http://junaidichaniago.wordpress.com/2010/04/21/download-tabel-tuntuk-d-f-1-200/ 